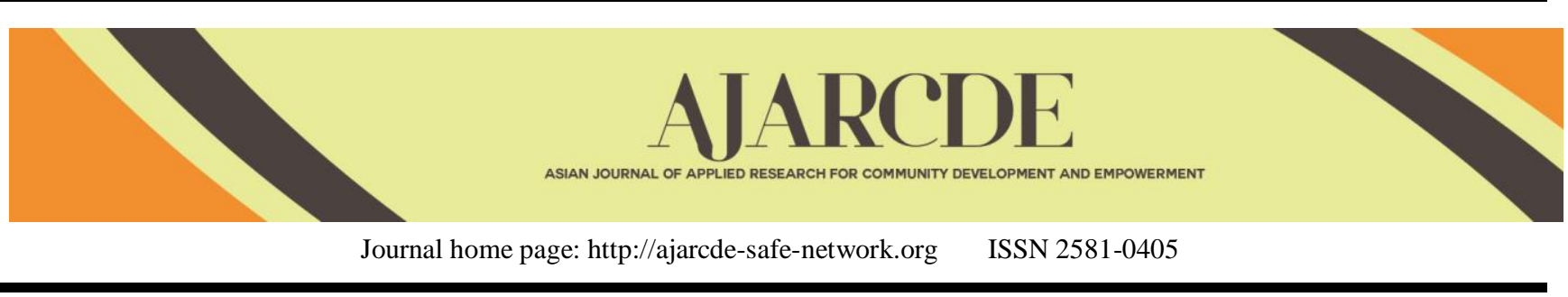

\title{
Nutritional Value of Cookies Made from the Mixture of Mocaf Flour (Modified Cassava Flour) and Ketapang seeds (Terminalia catappa L.)
}

\author{
Rina Yenrina, Tuty Anggraini, Annesa Kadri \\ ${ }^{1}$ Department of Agricultural Processing Technology, Andalas University, Limau Manis, Padang, 25166, Indonesia
}

\section{ARTICLE INFO}

Article History:

Received: 19 January 20

Final Revision: 27 March 20

Accepted: 19 April 20

Online Publication: 20 April 20

\section{KEYWORDS}

ketapang seed, mocaf, characteristic, cookies,

Terminalia catappa $\mathrm{L}$

\section{CORRESPONDING AUTHOR}

E-mail: yenrinarusdi@yahoo.co.id

\section{INTRODUCTION}

\subsection{Research Background}

One of the agricultural products that become the basic needs of Indonesian people is wheat flour. Efforts in developing food products continue to be carried out such as utilizing local commodities so that the processing of non-wheat flour can be used as a substitute for making food products in order to overcome dependence on wheat flour [1].

Cassava flour which has been modified by fermentation treatment, has physical characteristics similar to flour such as, has a smoothness and color similar to flour, so that it can be used as a substitute for flour or flour mixture. This modified cassava flour is known as MOCAF (Modified cassava flour). Various techniques have been developed to produce the characteristics of MOCAF flour with better quality, including nutrient content and the form of flour [2].

One product that can be made from MOCAF flour is cookies. Cookies are roasted food products made with basic ingredients of wheat flour, with a final water content of less than 5\% [3]. Cookies formulations are usually made with enriched other additives such as fat, sugar, and developer ingredients. In addition to the nutritional value contained in it, the quality of cookies is also determined by the color, aroma, taste and crispness [3].
MOCAF flour does not have as much protein content as wheat flour, so protein enrichment is needed from various other food sources. One of them is through the addition of ketapang seeds from the fruit of the ketapang tree (Terminallia catappa, L). Ketapang fruit seeds will be processed and used as one source of protein which will add to the nutritional content of MOCAF flour which is high in carbohydrates.

Ketapang trees also produce ketapang fruit. Ketapang fruit usually only become scattered waste when the fruit is brown. Ketapang fruit will fall to the ground by itself and just be left just like that to become waste, this happens because many people do not know that ketapang fruit can be utilized. Ketapang fruit can be consumed because there are ketapang seeds inside the fruit, which can be eaten directly and have a taste similar to peanuts.

In several countries in the world such as Nigeria, many residents have used ketapang fruit seeds to fortify foodstuffs that usually contain low protein content [4]. Usually children in Nigeria break up the endocarp and eat the seeds contained in the fruit of the ketapang and so far there have been no reports relating to the problem of poisoning at the time of consuming it or there have been no reports related to its toxicity [5].

The toxin found in ketapang is thought to originate from one of its proteins, namely lectins. According to previous studies, the lectin content contained in ketapang fruit seeds was found in small amounts, even basically non-toxic, so it had the potential as a source of protein for humans and animals. The lectin found in 
ketapang fruit seeds can cause blood clots in the body, but research conducted on mice shows that mice that are fed with ketapang fruit do not agglutinate mouse erythrocytes and can even digest ketapang seed protein well, as evidenced by rat body weight gain. slowly within 10 days of observation [6].

Ketapang seeds have a protein content of $25.3 \%$, fiber at $11.75 \%$, carbohydrates as much as $5.8 \%$, and fat at $16.35 \%$ as well as various kinds of amino acids, magnesium, calcium, iron, zinc, vitamin A, vitamin C, sodium, phosphorus, and manganese [7]. According to previous research, the proximate content of ketapang fruit seeds included protein (33.69\%), fiber $(3.1 \%)$, carbohydrates $(25.47 \%)$, fat $(32.73 \%)$, and there were 534.20 kcal. The high calorie content contained in ketapang fruit seeds can be used as a source of energy [8]. In an effort to increase the nutritional content and functional properties.

Many food products on the market are only high in certain nutritional content. For example, high in carbohydrates and fat but low in protein, of course this will have an unfavorable impact on consumers if consumed in a long time [9].

\subsection{Research Objective}

This study aims to determine the effect of comparison of MOCAF flour and ketapang fruit seeds on physical, chemical, and organoleptic characteristics of cookies and determine the best percentage of MOCAF flour and ketapang fruit seeds in making cookies.

\section{MATERIALS AND METHODS}

\subsection{Materials and Equipments}

The ingredients used in the manufacture of products are mocaf flour, ketapang fruit seeds, sugar, margarine, egg yolk, baking powder, full cream milk powder and salt. The chemicals used for analysis included $0.1 \mathrm{~N} \mathrm{NaOH}$, Benzene, 95\% alcohol, phenolptalein (PP) indicator, filter paper, concentrated $\mathrm{H}_{2} \mathrm{SO}_{4}$, selenium mix.

The tools used are ovens, grinders, mixers, trays, plastic containers, measuring cups, analytical scales, time gauges, stoves, pans, jars, ovens, eyela and drying containers. The analytical tool used is the water content oven, analytical balance, hot plate, furnace, desiccator, standard, clamps, cup pliers, aluminum plates, porcelain cups, Erlenmeyer, measuring cups, goblets, measuring flasks, measuring pipettes, drop pipettes, burettes, Kjeltec Analysis, Soxtec 2050 and bomb calorimeter.

\subsection{Research Design}

The design used in this study was a completely randomized design (CRD) with 5 treatments and 3 replications. The treatments in this study are:

Treatment A: MOCAF Flour (100\%) ketapang seed $(0 \%)$

Treatment B: MOCAF Flour (90\%): ketapang seed $(10 \%)$

Treatment C: MOCAF Flour (80\%): ketapang seed (20\%)

Treatment D: MOCAF Flour (70\%): ketapang seed $(30 \%)$

Treatment E: MOCAF Flour (60\%): ketapang seed (40\%)

\subsection{Research Implementation}

\subsection{1. $\quad$ Processing of Ketapang Fruit Seeds}

Before processing according to Ref. [11], fresh seeds should be assessed for freshness. This is done with the aim to determine the good seeds and ready to be processed. This freshness assessment is determined based on the color and physical condition of the seeds. A good seed is a seed that has a light brown outer skin, with a white inside.

After the ketapang fruit has been collected then proceed with the drying process to reduce the water content of the outer skin of the ketapang fruit, after the water content has decreased the ketapang fruit is broken down so that the seeds can be taken, the outer skin of the ketapang seeds is brown while the inside is white, then the seeds of the ketapang are washed and oven dried at ${ }^{60 \mathrm{oC}}$ until the water content is less than $10 \%$ [12]. Furthermore, Ketapang seeds that have been dried and then ground using a grinder.

\subsubsection{Formulation}

Table 1. Cookies Formulations based on Treatment

\begin{tabular}{|c|c|c|c|c|c|}
\hline \multirow[t]{2}{*}{ Materials } & \multicolumn{5}{|c|}{ Treatment } \\
\hline & $\mathrm{A}$ & B & $\mathrm{C}$ & $\mathrm{D}$ & $\mathrm{E}$ \\
\hline MOCAF (g) & 100 & 90 & 80 & 70 & 60 \\
\hline Ketapang (g) & 0 & 10 & 20 & 30 & 40 \\
\hline Margarine (g) & 50 & 50 & 50 & 50 & 50 \\
\hline Salt $(g)$ & 1 & 1 & 1 & 1 & 1 \\
\hline Sugar $(g)$ & 50 & 50 & 50 & 50 & 50 \\
\hline Full cream milk powder $(\mathrm{g})$ & 15 & 15 & 15 & 15 & 15 \\
\hline Egg yolk $(\mathrm{g})$ & 20 & 20 & 20 & 20 & 20 \\
\hline Baking powder (g) & 4 & 4 & 4 & 4 & 4 \\
\hline
\end{tabular}

\subsubsection{Cookies Making Stage}

The steps in making cookies according to Ref. [10] with a few modifications are:

1. Margarine, full cream milk powder and refined sugar are mixed and stirred until homogeneous.

2. Then add the egg yolks and salt slowly into the mixture and stir until homogeneous.
3. After all ingredients are mixed add MOCAF flour, ketapang fruit seeds and baking powder slowly and the mixture is stirred until homogeneous.

4. The dough is rolled until it is shaped like a sheet which is then printed with a mold.

5. Then baked in an oven at $160^{\circ} \mathrm{C}$ for 10 minutes. After it is cold, the packaging is done using a closed container. 


\subsection{Observations}

Observation of ketapang seeds includes a chemical analysis consisting of analysis of water content, ash content, protein content, fat content and carbohydrate content. While the analysis conducted on the product is a chemical analysis consisting of analysis of water content, ash content, protein content, fat content, free fatty acid levels, carbohydrates and energy values. While physical analysis includes product texture (hardness) and organoleptic tests with hedonic scale tests including color, aroma, taste, texture (crispness) in cookies.

\section{RESULT AND DISCUSSION}

\subsection{Nutritional Content of Ketapang Seeds}

Analysis of raw materials needs to be done to determine the amount of nutrient content of raw materials before and after processing. Analysis carried out on the dried ketapang fruit including the analysis of water content, ash content, fat, protein and carbohydrates contained in an ingredient. The nutritional content of ketapang fruit seeds can be seen in Table 2 .

Table 2. Nutritional Content of Ketapang Seeds

\begin{tabular}{lll}
\hline Parameter & $\begin{array}{l}\text { Ketapang } \\
\text { Deviation }\end{array}$ & \pm Standard \\
\hline Moisture Content & $5.31 \pm 0.01$ & \\
Ash & $4.46 \pm 0.23$ & \\
Protein & $22.23 \pm 0.19$ & \\
Fat & $52.78 \pm 0.11$ & \\
Carbohydrate & $15.22 \pm 0.67$ & \\
\hline
\end{tabular}

It can be seen that the moisture content of ketapang fruit seeds is $5.31 \%$ (Table 2). The value of the water content of the Ketapang seeds is influenced by the drying process, because the Ketapang seeds which have just been released from the Ketapang fruit shell are still in a damp condition, so that the drying process is needed after the release of the fruit shells, because the Ketapang seeds are not directly used then the drying process is needed so that the fruit seeds can be stored until the seeds are processed to the next processing stage.

The water content of ketapang seeds will affect the shelf life of ketapang seeds to be longer, generally high water levels can accelerate the growth of microorganisms and accelerate damage to food. In addition, the $14-15 \%$ moisture content found in dried food is sufficient to prevent mold growth [13]. The results of ketapang seed water content were $5.31 \%$, close to the research conducted by Ref. 14] which was $4.8 \%$ and research conducted by Ref. [15]. with the water content obtained by $5 \mathrm{~g} / 100 \mathrm{~g}$

Ketapang fruit seed ash content obtained was $4.46 \%$ while according to research by Ref. [14], ash content obtained was $4.6 \%$ and according to Ref. [8] ash content obtained was 5\%., then the ash content results obtained approaching existing research. Ash content determines the amount of minerals found in an ingredient. Minerals contained in ketapang seeds include phosphorus, sodium, potassium, iron, calcium, magnesium, copper and zinc [8]..

The protein contained in the ketapang seeds obtained was $22.23 \%$ while according to the research by Ref. [14], the amount of protein content was $29.89 \%$ so that the value of the protein content in the ketapang seeds analyzed was close to the existing Yenrina et al. research. According to Ref. [8], the protein of ketapang fruit seeds is $33.69 \%$, the high value of protein contained in ketapang fruit seeds can be used as a source of protein for people who need protein derived from plants.

The fat content in the ketapang seeds is $52.78 \%$, almost half of the weight of the ketapang seeds consists of fat, when compared with research by Ref. [16], the fat content contained was $60 \%$, so if is compared with the research by Ref. [14], where fat content contained in ketapang seeds amounted to $63.65 \%$, the amount of fat that has been analyzed is close to the research that has been done before. The high fat content found in ketapang fruit seeds due to the presence of fatty acids, including oleic acid, linoleic acid, palmitic acid, stearic acid, lauric acid and myristic acid. Fats contained in ketapang seeds are generally unsaturated fats, namely monounsaturated fatty acids such as oleic acid and linoleic acid [16].

Carbohydrates or carbohydrate contained in ketapang seeds amounted to $15.22 \%$ obtained by the by difference method. The results obtained are higher when compared to research conducted by Ref. [14] which is equal to $5.09 \%$ and Ref. [4] has a carbohydrate value of $11.95 \%$.

\subsection{Chemical Analysis of Cookies}

\subsubsection{Water content}

Water content is the amount of water contained in food. Analysis of variance showed that the comparison of MOCAF flour with ketapang fruit seeds in making cookies was not significantly different at $\alpha=5 \%$ level of water content of the cookies produced (Table 3 ).

Table 3. Average Cookies Moisture Value

\begin{tabular}{ll}
\hline Treatment & Moisture Content $(\%) \pm$ SD \\
\hline A $(100 \%: 0 \%)$ & $2.78 \pm 0.20$ \\
B $(90 \%: 10 \%)$ & $3.00 \pm 0.33$ \\
C $(80 \%: 20 \%)$ & $3.10 \pm 0.51$ \\
D $(70 \%: 30 \%)$ & $3.11 \pm 0.20$ \\
E $(60 \%: 40 \%)$ & $3.22 \pm 1.02$ \\
\hline CV $\mathbf{1 7 . 8 8 \%}$ &
\end{tabular}

The results of the analysis of cookies water content ranged from $2.78 \%-3.22 \%$ (Table 3). Cookies with treatment A (100\% MOCAF flour: $0 \%$ ketapang fruit seeds) had the lowest water content with a value of $2.78 \%$ while cookies with treatment $\mathrm{E}$ (60\% MOCAF flour: $40 \%$ ketapang seeds) had a moisture content of $3.22 \%$, this is influenced by the high proportion of ketapang seeds used which will have an impact on the higher moisture content of cookies, this is because ketapang fruit seeds contain high fat, which will increase the amount of fat solids in cookies thus reducing the level of starch [17].

The influence of starch content derived from MOCAF flour used will give effect to the water content of cookies, because MOCAF flour has amylose content that is easy to absorb and release water, so when cookies undergo a roasting process, the water in the material will be easily released. this causes the water content in the material will be lower [17].

The higher the water content in food, the greater the risk of damage that occurs during the storage process of the material, for this reason it is necessary to have a minimum water content to inhibit the growth of bacteria, mold and yeast that will damage 
food. Judging from the value of the moisture content of cookies, all treatments have met the Indonesian National Standard (SNI) 2973: 2011 which is a maximum of $5 \%$.

\subsubsection{Ash Levels}

Statistical test results from the analysis of variance showed that the comparison of MOCAF flour with ketapang fruit seeds in making cookies was not significantly different at $\alpha=5 \%$ level on the ash content of the cookies produced (Table 4).

Table 4. Ash Content of Cookies

\begin{tabular}{ll}
\hline Treatment & Ash $(\%) \pm$ SD \\
\hline A $(100 \%: 0 \%)$ & $2.77 \pm 0.51$ \\
B $(90 \%: 10 \%)$ & $2.89 \pm 0.38$ \\
C $(80 \%: 20 \%)$ & $2.99 \pm 0.33$ \\
D $(70 \%: 30 \%)$ & $3.00 \pm 0.33$ \\
E $(60 \%: 40 \%)$ & $3.33 \pm 0.58$ \\
\hline CV $=\mathbf{4 . 6 1 \%}$ & \\
\hline
\end{tabular}

It is known that the results of the analysis of the ash content of cookies range from $2.77 \%-3.33 \%$ (Table 4 ). This shows that the ash content of cookies from all treatments exceeds the maximum limit made by the Indonesian National Standard (SNI) 2973: 2011 which is a maximum of $1.5 \%$.

Cookies with A treatment $(100 \%$ MOCAF flour: $0 \%$ ketapang fruit seeds) have the lowest ash content of $2.77 \%$ but still have a value exceeding the limits set by SNI of $1.5 \%$, while cookies with E treatment (flour MOCAF 60\%: Ketapang fruit seeds $40 \%$ ) have the highest ash content of $3.33 \%$.

Factors that influence the ash content of cookies are derived from MOCAF flour and ketapang fruit seeds used. According to Ref. [18]. MOCAF flour ash content was $0.37 \%$, while the ash content of ketapang fruit seeds was $4.46 \%$. MOCAF flour ash content is lower than ash content of ketapang fruit seeds, but cookies that are not added to Ketapang fruit seeds still have mineral content that exceeds the limits of SNI, this is due to the formulation of adding additional ingredients in making cookies. Other ingredients containing minerals are thought to originate from the addition of baking powder, margarine, milk and eggs.

Minerals contained in ketapang seeds include phosphorus, sodium, potassium, iron, calcium, magnesium, copper and zinc [8] with the addition of ketapang seeds to the cookie formulation, the ash content of cookies obtained will increase .

\subsubsection{Protein Content}

Statistical test results from the analysis of variance showed that the comparison of MOCAF flour with ketapang fruit seeds in making cookies was significantly different at $\alpha=5 \%$ level of the protein content of the cookies produced (Table 5).

It is known that the results of the analysis of protein cookies range between $3.03 \%-6.85 \%$ (Table 5), while the protein cookies content made by the Indonesian National Standard (SNI) 2973: 2011 is at least $5 \%$. of all treatments, there were three treatments that did not reach Indonesian National Standards, namely A treatment (100\% MOCAF flour: $0 \%$ ketapang fruit seeds), B (90\% MOCAF flour: 10\% ketapang fruit seeds) and C (80\% MOCAF flour: seeds ketapang $20 \%$ ) which has a protein content of less than $5 \%$.
Table 5. Protein Content of Cookies

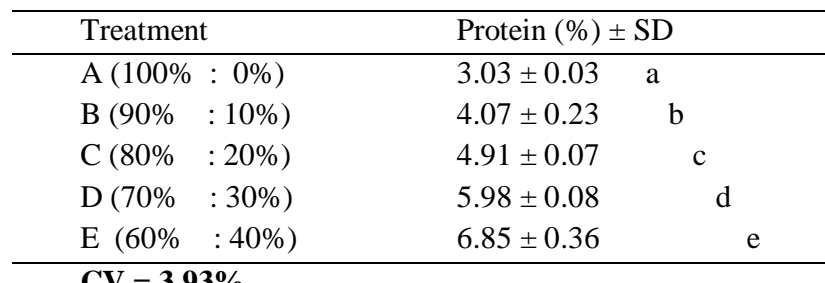

Note: Figures in the same row are followed by lowercase letters which are not the same that differ significantly at the 5\% level according to DNMRT. $\mathrm{SD}=$ Standard Deviation

This is due to originating from the raw material used which is the effect of MOCAF flour which contains a fairly low protein that is equal to $2.65 \%$ [18], although additional ingredients in making cookies contain milk and eggs that contain protein, but have not been able to reach the protein levels set by SNI 2973: 2011.

There are two cookies treatments that exceed the Indonesian National Standard, namely D treatment (70\% MOCAF flour: $30 \%$ ketapang fruit seeds) which has a protein content of $5.98 \%$ and E treatment (60\% MOCAF flour: $40 \%$ ketapang fruit seeds) containing protein at $6.85 \%$. This is due to the increase in the addition of ketapang fruit seeds to MOCAF flour thereby increasing the protein content of the cookies produced. The protein content of ketapang seeds is quite high at $22.23 \%$, so that it can compensate for the low protein content of MOCAF flour, with the addition of ketapang seeds being done, it will increase the content of the protein cookies produced.

\subsubsection{Fat Content}

Statistical test results from the analysis of variance showed that the comparison of MOCAF flour with ketapang seeds in making cookies was significantly different at $\alpha=5 \%$ level of fat content of the cookies (Table 6). Based on Table 6. it is known that the results of the analysis of cookies fat content ranged from $20.02 \%-29.65 \%$. The cookies with treatment A (100\% MOCAF flour: $0 \%$ ketapang fruit seeds) have the lowest fat content value which is equal to $20.02 \%$.

Table 6. Cookies Fat Content

\begin{tabular}{llr}
\hline Treatment & Fat $(\%) \pm \mathrm{SD}$ & \\
\hline A $(100 \%: 0 \%)$ & $20.02 \pm 2.26$ & $\mathrm{a}$ \\
B $(90 \%: 10 \%)$ & $23.22 \pm 0.11$ & $\mathrm{~b}$ \\
C $(80 \%: 20 \%)$ & $26.87 \pm 2.29$ & $\mathrm{c}$ \\
D $(70 \%: 30 \%)$ & $27.09 \pm 0.76$ & $\mathrm{c}$ \\
E $(60 \%: 40 \%)$ & $29.65 \pm 0.97$ & $\mathrm{c}$ \\
\hline
\end{tabular}

\section{$\mathrm{CV}=\mathbf{6 . 0 8 \%}$}

Note: Figures in the same lane followed by lowercase letters which are not significantly different at the $5 \%$ level according to DNMRT SD $=$ Standard Deviation

Treatment A (100\% MOCAF flour: 0\% ketapang fruit seeds) was not added ketapang fruit seeds but the fat content contained had complied with National Standard 01 - 2973-1992 which was $9.5 \%$, this was due to the cookie formulation added milk, eggs and margarine, so the fat content in treatment A comes from the addition of milk, egg yolks and margarine. 
Treatment E cookies (60\% MOCAF flour: 40\% ketapang fruit seeds) had the highest fat content with $29.65 \%$. Factors that influence the increase in fat content comes from the addition of ketapang fruit seeds, because the Ketapang fruit seeds have a high fat content that is equal to $52.78 \%$, so that with the addition of more ketapang seeds, it will further increase the fat content of the cookies produced. Judging from the value of cookies fat content of all treatments, the fat content of cookies has fulfilled the Indonesian National Standard (SNI) 01 - 2973-1992, which is a minimum of $9.5 \%$.

\subsubsection{Carbohydrate Content}

Statistical test results from the analysis of variance showed that the comparison of MOCAF flour with ketapang fruit seeds in making cookies was significantly different at $\alpha=5 \%$ level on the carbohydrate content of the cookies produced (Table 7).

Table 7. Carbohydrate Content of Cookies

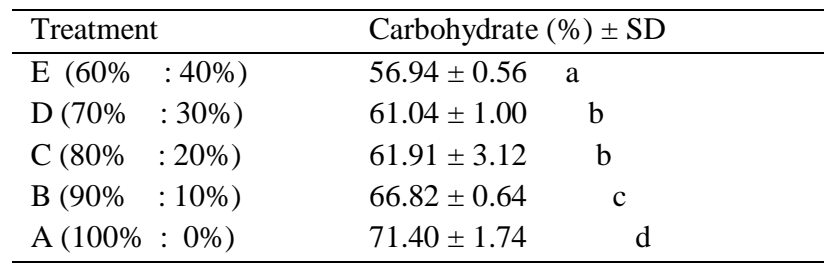

\section{$\mathrm{CV}=\mathbf{2 . 0 6 \%}$}

Note: Figures in the same lane followed by lowercase letters which are not significantly different at the 5\% level according to DNMRT SD $=$ Standard Deviation

Based on Table 7, it is known that the results of the analysis of carbohydrate cookies range from $56.94 \%-71.40 \%$, while the carbohydrate content of cookies is determined by the Indonesian National Standard (SNI) 2973: 1992 which is at least 70\%. But of the five cookies treatments only one treatment that fulfilled SNI namely treatment A (100\% MOCAF flour: 0\% ketapang fruit seeds) with carbohydrates of $71.40 \%$, this was influenced by the content of amylose and amylopectin derived from MOCAF flour of 82, 97\% [18], treatment A (100\% MOCAF flour: 0\% ketapang fruit seeds) which did not experience the addition of ketapang fruit had a higher carbohydrate value than the treatment that experienced the addition of ketapang fruit seeds.

Cookies with E treatment (MOCAF flour 60\%: ketapang fruit seeds $40 \%$ ) contain the lowest levels of carbohydrates, because the addition of ketapang fruit seeds on treatment $E$ (MOCAF flour 60\%: $40 \%$ ketapang fruit seeds) is the greatest addition among all treatments .

Cookies with the addition of ketapang seeds will have a high fat content, this is because fat derived from ketapang seeds will increase the amount of fat solids in cookies thus reducing the level of the starch. The correlation between fat and carbohydrate content produces a negative correlation which means that if the cookies formed have high fat content, the carbohydrate level is low [17].

\subsubsection{Energy Value}

The analysis of variance showed that the comparison of MOCAF flour with ketapang fruit seeds in making cookies was significantly different at $\alpha=5 \%$ to the energy value of the cookies produced (Table 8)
Table 8. Average Energy Value of Cookies

\begin{tabular}{lll}
\hline Treatment & \multicolumn{2}{l}{ Energy Value (kcal) \pm SD } \\
\hline A $(100 \%: 0 \%)$ & $475.85 \pm 15.69$ & a \\
B $(90 \%: 10 \%)$ & $476.27 \pm 9.85$ & a \\
C $(80 \%: 20 \%)$ & $504.55 \pm 14.17$ & b \\
D $(70 \%: 30 \%)$ & $523.07 \pm 8.07$ & bc \\
E $(60 \%: 40 \%)$ & $536.95 \pm 7.30$ & c \\
\hline
\end{tabular}

$\mathrm{CV}=\mathbf{2 . 2 9 \%}$

Note: Figures in the same lane followed by lowercase letters which are not significantly different at the $5 \%$ level according to DNMRT SD $=$ Standard Deviation

Based on Table 8, it is known that the results of the analysis of the energy value of cookies in 100 grams range between 475.85 $\mathrm{kcal}-536.95 \mathrm{kcal}$. Based on Table 13 it can be seen that cookies with treatment A (100\% MOCAF flour: $0 \%$ ketapang fruit seeds) have the lowest energy value of $475.85 \mathrm{kcal}$ and cookies with treatment E (MOCAF flour 60\%: ketapang fruit seeds $40 \%$ ) have a value the highest energy is $536.95 \mathrm{kcal}$, so the energy value of all cookie treatments is above the National Standard (SNI) 01 2973-1992 which is a minimum of $400 \mathrm{kcal}$ per 100 grams.

Cookies with treatment A (100\% MOCAF flour: 0\% ketapang fruit seeds), even without the addition of ketapang fruit seeds still meet the minimum energy value specified by SNI 01 2973 - 1992, because cookies with treatment A (100\% MOCAF flour: Ketapang fruit seeds $0 \%$ ) have a carbohydrate value of 71.40 which also meets SNI 01-2973-1992 which is at least 70\%.

For the treatment of cookies B (90\% MOCAF flour: $10 \%$ ketapang seeds), C (80\% MOCAF flour: $20 \%$ ketapang seeds), D (MOCAF flour 70\%: 30\% ketapang seeds) and E (MOCAF flour $60 \%$ : Ketapang fruit seeds $40 \%$ ) which experienced the addition of Ketapang fruit seeds have an energy value that is sufficient for the energy value determined by SNI 01-2973-1992, although the carbohydrate content does not meet SNI 01-2973-1992. This is due to the many components other than carbohydrate contained in cookies such as fat and protein. Fat produces $9 \mathrm{kcal} / \mathrm{g}$ while protein produces $4 \mathrm{kcal} / \mathrm{g}$, so fat and protein in cookies produced can be used as a source of energy other than carbohydrates.

\subsubsection{Free Fatty Acids}

The fat component of the oil is in the form of glycerides, namely esters between glycerol (alcohol) and fatty acids. Glycerides are easily broken down into fatty acids and glycerol through the process of heating (temperature), oxidation, hydrolysis, light and certain metals such as $\mathrm{Cu}, \mathrm{Mn}$ and $\mathrm{Fe}$ which are prooxidants in fat [19]. Fatty acids released from glycerol are called free fatty acids. The content of free fatty acids found in cookies comes from the hydrolysis process, damage due to hydrolysis is called hydrolytic rancidity or rancidity. The hydrolysis process occurs because there is a certain amount of water in the fat [19].

Statistical test results from the analysis of variance showed that the comparison of MOCAF flour with ketapang seeds in making cookies was significantly different at $\alpha=5 \%$ to the value of free fatty acids from the cookies produced. The average value of free fatty acid cookies can be seen in Table 9 .

Based on Table 9, it is known that the analysis of the value of cookies free fatty acids ranges from $0.28 \%-0.38 \%$, with the lowest free fatty acid content found in treatment A $(100 \%$ MOCAF flour: 0\% ketapang fruit seeds), B (MOCAF flour 90\%: 
ketapang fruit seeds 10\%), C (MOCAF flour 80\%: ketapang fruit seeds 20\%) and D (MOCAF flour 70\%: ketapang fruit seeds $30 \%$ ) while treatment $\mathrm{E}$ (MOCAF flour $60 \%$ : ketapang fruit seeds $40 \%$ ) has the highest free fatty acid content compared to other treatments that is equal to $0.38 \%$.

Table 9. Free Fatty Acid Content of Cookies

\begin{tabular}{|c|c|}
\hline Treatment & Free Fatty Acid $(\%) \pm$ SD \\
\hline $\mathrm{A}(100 \%: 0 \%)$ & $0.28 \pm 0.00 \quad \mathrm{a}$ \\
\hline B (90\% : $10 \%)$ & $0.28 \pm 0.00$ \\
\hline $\mathrm{C}(80 \%$ & $0.28 \pm 0.00$ \\
\hline $\mathrm{D}(70 \%$ & $0.28 \pm 0.00$ \\
\hline E $(60 \%$ & $0.38 \pm 0.03$ \\
\hline
\end{tabular}

$\mathrm{CV}=\mathbf{4 . 3 2 \%}$

Note: Figures in the same lane followed by lowercase letters which are not significantly different at the 5\% level according to DNMRT SD = Standard Deviation

Analysis of the free fatty acid levels of the five cookies treatments did not pass the free fatty acid quality standard set by SNI 2973: 2011 which was a maximum of 1.0\%, this was because during the processing process, the most dominant component in these cookies was the fat component, both of which comes from raw materials namely ketapang fruit seeds or from additional ingredients such as margarine, milk and eggs.

Data on free fatty acid content of cookies shows that high water and fat content will produce high free fatty acids because the hydrolysis process which causes water in fat will experience fat damage due to hydrolysis process [20]. based on treatment $\mathrm{E}$ (MOCAF flour $60 \%$ : Ketapang fruit seeds $40 \%$ ) which have a moisture content of $3.22 \%$ and a fat content of $29.65 \%$ produce the highest free fatty acid content that is equal to $0.38 \%$.

\subsection{Physical Analysis of Cookies}

\subsubsection{Hardness}

Statistical test results from the analysis of variance showed that the comparison of MOCAF flour with ketapang fruit seeds in making cookies was significantly different at $\alpha=5 \%$ against the hardness value of the cookies produced (Table 10).

Table 10. Average Cookies Hardness Values

\begin{tabular}{llll}
\hline Treatment & Hardness $\left(\mathrm{N} / \mathrm{cm}^{2}\right) \pm \mathrm{SD}$ \\
\hline A $(100 \%: 0 \%)$ & $267.32 \pm 7.73$ & $\mathrm{a}$ & \\
B $(90 \%: 10 \%)$ & $283.25 \pm 9.78$ & $\mathrm{~b}$ & \\
C $(80 \%: 20 \%)$ & $305.29 \pm 6.53$ & $\mathrm{c}$ & \\
D $(70 \%: 30 \%)$ & $337.16 \pm 4.20$ & $\mathrm{~d}$ \\
E $(60 \%: 40 \%)$ & $360.40 \pm 7.25$ & \multicolumn{2}{c}{$\mathrm{e}$} \\
\hline CV $=\mathbf{2 . 3 6 \%}$ & &
\end{tabular}

Note: Figures in the same lane followed by lowercase letters which are not significantly different at the 5\% level according to DNMRT SD $=$ Standard Deviation

It is known that the results of the analysis of the value of cookies hardness ranges from $267.32 \mathrm{~N} / \mathrm{cm}^{2}-360.40 \mathrm{~N} / \mathrm{cm}^{2}$, so the higher the value of the hardness that is obtained, the resulting cookies are getting harder (Table 10). Cookies with treatment A (100\% MOCAF flour: 0\% ketapang seeds) had the lowest hardness value while cookies with product $\mathrm{E}$ treatment (MOCAF flour 60\%: 40\% ketapang seeds) had the highest hardness value.
This is suspected because there are differences in the components contained in it, treatment A (100\% MOCAF flour: $0 \%$ ketapang seeds). The content of amylose and amylopectin contained in treatment A cookies (100\% MOCAF flour: 0\% ketapang seeds) is more dominant, amylose will form a harder, adhesive and compact flour gel [21], so it will affect against cookie hardness, while amylopectin is stimulating the blooming process (puffing), so that the food products produced are crisp, light, porous and crisp [22].

Cookies treatment E (MOCAF flour 60\%: ketapang seeds $40 \%$ ) with the addition of the highest ketapang seeds has a moisture content of $3.22 \%$, which will increase the hardness of the cookies produced, this is caused by ketapang seeds having components other than carbohydrates greater so that it can affect the nature of cell walls and air cavity cookies formed [9]

Ketapang seeds have a fairly low carbohydrate content of $15.24 \%$ so that it will have an effect on the value of cookie hardness. The more ketapang seeds added to each treatment will increase the value of hardness on the resulting cookie products.

Food texture is determined by water content, fat content and structural carbohydrate content such as cellulose, starch and pectin ingredients and proteins contained in a product. Changes in texture are usually caused by an increase in water content or fat loss, emulsion formation, carbohydrate hydrolysis and coagulation [23].

\subsection{Microbiological Analysis}

\subsubsection{Total Plate Number}

Microbiological analysis is one of the important analyzes, in addition to being used as an indicator of sanitation in food before the food is suitable for consumption by consumers and can predict the shelf life of a food (Table 11).

Mesophile and anaerobic aerobic total plate count using solid media with the final results in the form of colonies that can be observed visually and counted, interpretation of the results in the form of colony numbers (cfu) per $\mathrm{ml} / \mathrm{g}$ or colonies / 100ml [24]. Based on Table 11 it is known that the number of colonies that grew on the testing of the total plate number of cookies ranged from $1.6 \times 103$ (cfu/g) - 9.1 x 103 (cfu / g). The results of testing the plate numbers of the five treatment cookies made from MOCAF flour and ketapang fruit seeds are within the limits set by the Indonesian National Standard (1 x 104 cfu / g), so that they are within the safe limit for consumption.

Table 11. Average Total Plate Count of Cookies

\begin{tabular}{ll}
\hline Treatment & ALT $(\mathrm{cfu} / \mathrm{g})$ \\
\hline A $(100 \%: 0 \%)$ & $2.7 \times 10^{3}$ \\
B $(90 \%: 10 \%)$ & $3.8 \times 10^{3}$ \\
C $(80 \%: 20 \%)$ & $5.0 \times 10^{3}$ \\
D $(70 \%: 30 \%)$ & $9.1 \times 10^{3}$ \\
E $(60 \%: 40 \%)$ & $1.6 \times 10^{3}$ \\
\hline
\end{tabular}

From the value of the total plate count obtained, it is thought to originate from the characteristics of the food itself such as the characteristics of cookies are fat, protein, and have a low water content, as well as processing factors, environmental conditions of the trade and storage of foodstuffs such as Cookies storage at room temperature. Dried food products usually have little or no 
bacteria but can contain mold. Conditions for mold growth include low water content, air temperature of $25-30{ }^{\circ} \mathrm{C}$, carbohydrate, protein or fat [25].

One of the microorganisms will become dominant in optimum growth conditions that can be recognized in food as a result of contamination from various different sources such as air, water, food additives, equipment, humans, and food packaging materials [26].

\subsection{Organoleptic Analysis}

\subsubsection{Color}

Color plays an important role as an attraction, identification and quality attributes. Color is a quality factor that most attracts the attention of consumers and determines first impressions, both likes and dislikes by consumers [27]. Statistical test results from the analysis of variance showed that the comparison of MOCAF flour with ketapang fruit seeds in making cookies was significantly different at $\alpha=5 \%$ level of the color of the cookies produced. The average color values can be seen in Table 12 .

Based on Table 12, it is known that the analysis of the color values of cookies ranges from 3.14 to 3.91 , this shows that the color of the cookies produced can be accepted by panelists at an ordinary level. The highest average value of panelists' preference for the color of cookies was obtained in cookies with treatment $\mathrm{C}$ (80\% MOCAF flour: 20\% ketapang fruit seeds) with a value of 3.14 and the lowest value was found in treatment $\mathrm{E}(60 \%$ MOCAF flour: ketapang seeds $40 \%$ ) with a value of 3.14 .

Table 12. Color Score of Cookies

\begin{tabular}{lll}
\hline \multicolumn{2}{l}{ Treatment } & \multicolumn{2}{l}{ Color \pm Standard of Deviation } \\
\hline E $(60 \%: 40 \%)$ & $3.14 \pm 1.08$ & $\mathrm{a}$ \\
D $(70 \%: 30 \%)$ & $3.66 \pm 0.83$ & $\mathrm{~b}$ \\
A $(100 \%: 0 \%)$ & $3.86 \pm 1.06$ & $\mathrm{~b}$ \\
B $(90 \%: 10 \%)$ & $3.86 \pm 0.73$ & $\mathrm{~b}$ \\
C $(80 \%: 20 \%)$ & $3.91 \pm 0.65$ & $\mathrm{~b}$ \\
\hline
\end{tabular}

$\mathrm{CV}=\mathbf{2 4 . 2 2 \%}$

Note: $5=$ very like, $4=$ like, $3=$ ordinary, $2=$ dislike, $1=$ very dislike

Based on the research carried out the more addition of ketapang fruit seeds, the color of the resulting cookies will be increasingly brown, thereby affecting the panelists' preference level, because panelists prefer $\mathrm{C}$ treatment cookies (80\% MOCAF flour: $20 \%$ ketapang t seeds) which have a light brown color.

The color contained in cookies is caused by the use of ketapang fruit seeds that have brown epidermis as well as a result of the Maillard reaction. Maillard reaction is a reaction that occurs between amino acids with reducing sugars which will form a brown color [19], so this color gives an influence on the cookies produced. Cookies that do not experience the addition of seeds of fruit ketapang cookies produced are yellow, this is due to the addition of margarine to cookies, the yellow color of margarine comes from beta carotene (pro-vitamin A) which is naturally contained in the original oil [17].

\subsubsection{Aroma}

The aroma is the smell of food products produced volatile compounds from a food into the nasal cavity and is felt by the olfactory system [28]. Statistical test results from the analysis of variance showed that the comparison of MOCAF flour with ketapang fruit seeds in making cookies was not significantly different at the level of $\alpha=5 \%$ of the aroma of the cookies produced (Table 13).

Tabel 13. Aroma score of Cookies

\begin{tabular}{ll}
\hline Treatment & Aroma \pm Standard of Deviation \\
\hline A $(100 \%: 0 \%)$ & $3.77 \pm 0.97$ \\
E $(60 \%: 40 \%)$ & $3.85 \pm 0.83$ \\
B $(90 \%: 10 \%)$ & $3.89 \pm 0.63$ \\
C $(80 \%: 20 \%)$ & $3.94 \pm 0.69$ \\
D $(70 \%: 30 \%)$ & $4.00 \pm 0.84$ \\
\hline
\end{tabular}

$\mathrm{CV}=\mathbf{2 0 . 6 5 \%}$

Note: 5 = very like, $4=$ like, $3=$ ordinary, $2=$ dislike, $1=$ very dislike

Based on Table 13, it is known that the analysis of the aroma value of cookies ranges from 3.77 to 4.00 , this shows that the aroma of cookies produced can be accepted by panelists at the level of ordinary to like. The highest average value of panelists' preference for the aroma of cookies was obtained in cookies with treatment D (70\% MOCAF flour: 30\% ketapang fruit seeds) with a value of 4.00 and the lowest value was found in treatment $A$ (100\% MOCAF flour: $0 \%$ ketapang seeds ) with a value of 3.77 .

In this research, the aroma of cookies produced is the typical aroma of ketapang fruit seeds. The aroma of cookies containing ketapang seeds comes from the fat content found in ketapang fruit seeds [29].

When cookies go through the baking process cookies will produce a savory aroma typical of ketapang fruit seeds. From the results of the average value of the aroma of cookies can be seen that the panelists liked the aroma of cookies of all treatments, it can be seen from the score of the average value of the aroma of cookies that are included in the category of likes.

\subsubsection{Flavor}

Flavor is the perception of taste cells including salty, sweet, sour and bitter taste caused by ingredients dissolved in the mouth [30].. Statistical test results from the analysis of variance showed that the comparison of MOCAF flour with ketapang fruit seeds on making cookies was significantly different at $\alpha=5 \%$ level on the taste of the cookies produced (Table 14).

Tabel 14. Flavor Score of Cookies

\begin{tabular}{lll}
\hline \multicolumn{2}{l}{ Treatment } & \multicolumn{2}{l}{ Flavor \pm Standard of Deviation } \\
\hline E $(60 \%: 40 \%)$ & $3.51 \pm 0.98$ & a \\
C $(80 \%: 20 \%)$ & $3.66 \pm 0.83$ & ab \\
D $(70 \%: 30 \%)$ & $3.66 \pm 0.80$ & ab \\
A $(100 \%: 0 \%)$ & $3.69 \pm 0.87$ & ab \\
B $(90 \%: 10 \%)$ & $4.00 \pm 0.80$ & $\mathrm{~b}$ \\
\hline CV $=\mathbf{2 3 . 2 6 \%}$ & & \\
\hline
\end{tabular}

Note: 5 = very like, 4 = like, $3=$ ordinary, $2=$ dislike, $1=$ very dislike

Based on Table 14 it is known that the analysis of the taste value of cookies ranges from $3.51-4.00$, from the average value of the taste of cookies shows that the taste of the resulting cookies can be accepted by panelists at the level of ordinary to like. The average value of the panelists' preference level for the highest 
taste of cookies was obtained in cookies with treatment B $(90 \%$ MOCAF flour: $10 \%$ ketapang fruit seeds) with a value of 4.00 and the lowest value was found in treatment $\mathrm{E}(60 \%$ MOCAF flour: ketapang fruit seeds $40 \%$ ) with a value of 3.51 .

This is because the addition of ketapang seeds to the cookies produced will give a sweet and savory taste derived from fat contained in the ketapang seeds, so that with the addition of ketapang seeds as much as $10 \%$ of the percentage of MOCAF flour has been able to balance the flavor derived from MOCAF flour .

\subsubsection{Crispness}

Crunchiness is the main quality of cookie products [20]. Statistical test results from the analysis of variance showed that the comparison of MOCAF flour with ketapang fruit seeds in making cookies was significantly different at $\alpha=5 \%$ level on the crispness of the cookies produced. The average value of crispness can be seen in Table 15 .

.Table 15. The Crispness of Cookies

\begin{tabular}{|c|c|c|}
\hline Treatment & Crispness \pm & \\
\hline $\mathrm{C}(80 \%: 20 \%)$ & $3.20 \pm 1.01$ & $\mathrm{a}$ \\
\hline $\mathrm{E}(60 \%: 40 \%)$ & $3.38 \pm 0.57$ & $\mathrm{a}$ \\
\hline $\mathrm{A}(100 \%: 0 \%)$ & $3.51 \pm 0.93$ & $\mathrm{a}$ \\
\hline $\mathrm{D}(70 \%: 30 \%)$ & $3.54 \pm 1.17$ & $\mathrm{a}$ \\
\hline B $(90 \%$ & $4.17 \pm 1.07$ & $\mathrm{~b}$ \\
\hline
\end{tabular}

$\mathrm{CV}=\mathbf{2 7 . 3 1 \%}$

Note: $5=$ very like, $4=$ like, $3=$ ordinary, $2=$ dislike, $1=$ very dislike

Based on Table 15, it is known that the analysis of cookies crispness ranges from 3.20 to 4.17 . This shows that the resulting crispness of cookies can be accepted by panelists on an ordinary to like level. The average value of panelists' preference level for the highest taste of cookies was obtained in cookies with treatment B (90\% MOCAF flour: 10\% ketapang seeds) with a value of 4.17 and the lowest value was found in treatment $C$ ( $80 \%$ MOCAF flour: $20 \%$ ketapang seeds ) with a value of 3.20 .

This is because the lower the starch content of an ingredient, the ability to bind the water is low, so the higher water content. The more constituent polysaccharides, it will increase the strength of stretching so that the ability to stretch is greater and resistant to breakage [17].,

In addition to water content, amylose and amylopectin levels also affect the crispness of cookies. Amylose will form starch gels which are harder, adhesive and compact [21]. while amylopectin is stimulating the blooming process (puffing), so that the food products produced are crispy, lighter, porous and crisp [22]. So

\section{REFERENCE}

[1] Marsigit, W., Bonodikun, dan L. Sitanggang. 2017. Pengaruh Penambahan Baking Powder dan Air Terhadap Karakteristik Sensoris dan Sifat Fisik Biskuit MOCAF (Modified Cassava Flour). Jurnal Agroindustri 7 (1) : 110.

[2] Salim, E. 2011. Mengolah Singkong Menjadi Tepung MOCAF Bisnis Produk Alternatif Pengganti Terigu. Lily Publisher. Yogyakarta.118 p.

[3] Suarti, B., E.A. AS, M. MD. 2015. Penambahan Tepung Daun Kelor dan Lama Pemanggangan Terhadap Mutu that the less addition of ketapang seeds and the addition of MOCAF flour will increase the crispness of the cookies product.

Fat content has an effect on reducing viscosity and starch development, while fat will inhibit less water penetration which will cause gelanitinization to be lower so that an increase occurs, an increase in the amount of fat that will increase the crispness of the cookies produced [31], hardness is the opposite of crispness, the greater the value of hardness, the more violent the product is produced, while the smaller the value of hardness, the crisper the product.

Based on panelists' preference level, cookies with treatment B (90\% MOCAF flour: 10\% ketapang seeds) with a value of 4.17 are cookies that have the crispness most preferred by panelists. This is influenced by the level of preference of each panelist so that it will give a different assessment on each product tested.

Tests carried out using a person's senses will affect the value given, according to the preferences that have been carried out by each panelist. Therefore the value obtained in testing the crispness of cookies in this study is quite different from the theory that has been explained.

\section{CONCLUSIONS}

Based on the research that has been done, the following conclusions can be drawn: (1). The comparison of MOCAF flour and ketapang fruit seeds used in making cookies has a significant effect on protein content, fat content, energy value, hardness, free fatty acids, carbohydrates and organoleptic tests in terms of color, crispness and taste. But it does not significantly affect the water content, ash content, and organoleptic test in terms of aroma, (2.) The best treatment based on chemical, physical and organoleptic acceptance is treatment cookies $\mathrm{E}$ with a ratio of $60 \%$ MOCAF flour and $40 \%$ ketapang fruit seeds with value average as follows: $3.22 \%$ water content, $6.85 \%$ ash content, $6.85 \%$ protein, $29.65 \%$ fat, $536.95 \mathrm{kcal}$ energy value, $360.40 \mathrm{~N} / \mathrm{cm}^{2}$ hardness, free fatty acids $0.38 \%$, carbohydrate $56.94 \%$, total plate number 1.6 x 103 , and organoleptic acceptance of MOCAF flour cookies and ketapang fruit seeds with an average color value of 3.14, aroma of 3.85, taste of 3.51 and crispness of 3.38 .

Based on the research that has been done, suggestions that can be given are processing the waste produced during the processing of ketapang fruit seeds to add economic value. Waste produced such as shells from the fruit of the ketapang originating from the process of taking the seeds of the ketapang fruit, the fruit shells of the ketapang produced quite a lot but have not been utilized. Further research is needed regarding the shelf life of cookie products.

Biskuit Dari MOCAF (Modified Cassava Flour). Agrium 19 (3) : 238-248.

[4] Makinde, F. M. and S.S. Oladunni. 2016. Effect of Processing Treatments on Nutritional Quality of Raw Almond (Terminalia catappa Linn.) Kernels. Advances in Applied Science Research 7(1) : 1-7.

[5] Ezeokonkwo, C.A. and W.L. Dodson. 2002. The Potential of Terminalia catappa (Tropical Almond) Seed As A Source of Dietary Protein. Journal of Food Quality $27: 207-219$

[6] Grant, G., More, L.J., McKenzie, N.H., Dorward, P.M., Buchan, W.C., Telek, L., Pusztai, A., 1995. Nutritional 
and hemagglutination properties of several tropical seeds. J. Agric. Sci. 124, 437-445.

[7] Husnaj, L. N., Meivitasari dan Pradekatiwi, 2010, Tempe dari Biji Ketapang, Skripsi,Fakultas MIPA UNY, Yogyakarta.

[8] Akpakpan, A.E., and U.D Akpabio.2012.Evaluation of Proximate Composition, Mineral Elements and AntiNutrient in Almond Seeds. Journal of Applied Science (7) : 9-12.

[9] Darmawan, E. 2016. Pemanfaatan Biji Ketapang (Terminalia catappa) Sebagai Sumber Protein dan Serat Pada Produk Makanan Stik. Jurnal Agrotech 1 (1) : 2733.

[10] Wulandari, M. dan E. Handasari. 2010. Pengaruh Penambahan Bekatul Terhadap Kadar Protein dan Sifat Organoleptik Biskuit. Jurnal Pangan dan Gizi 2 (2) : 5562.

[11] Faizal, M., P. Noprianto, dan R. Amelia. 2009. Pengaruh Jenis Pelarut, Massa Biji, Ukuran Partikel dan Jumlah Siklus Terhadap Yield Ekstraksi Minyak Biji Ketapang. Jurnal Teknik Kimia 16 (2) : 28-34.

[12] Janporn, S., C.T. Ho, V. Chavasit and M.H. Pan. 2015. Physicochemical Properties of Terminalia catappa Seed Oil as A Novel Dietary Lipid Source. Journal Food and Drug Analysis $23: 201-209$.

[13] Muchtadi, T.R. dan Sugiyono. 2013. Prinsip Proses dan Teknologi Pangan. Alfabeta. Bandung. 320 hal.

[14] Monnet, Y.T., A. Gbogouri, P.K.B. Koffi, and L.P. Kouame. 2012. Chemical Characterization Of Seed and Seed Oils Form Mature Terminalian catappa Fruits Harvested in Cote D'ivoire. International Journal of Biosciences 2 (1) : 110-124.

[15] Anuforo, P.C., N.K. Achi, A.C.C.Egbuonu, and E.U. Egu. 2017. Proximate Analysis and Determination of Some Selected Vitamins and Minerals Content of Terminalia catappa Endocarp Flour. Journal of Nutritional Health and Food Science : Hal 1-4.

[16] Weerawatanakorn, M., S. Janporn, C.T. Ho, and V. Chavasit. 2015. Terminalia catappa Linn Seeds As A New Food Source. Journal Science Technology 37 (5) : 507514.

[17] Nurud Diniyah, Achmad Subagio, Riri Nur Lutfian Sari, Pradiska Gita Vindy, Alif Ainur Rofiah.. 2018. Effect of Fermentation Time and Cassava Varieties on Water Content and the Yield of Starch from Modified Cassava Flour (MOCAF). Indonesian Journal of Pharmaceutical Science and Technology Vo 5 (2); $71-75$
[18] Yenrina, R. W.S. Murtius dan N.N. Putri. 2013. Mocaf Bread Enriched With Mung Bean (Vigna radiate L.) as A Source of Protein. Asia Pasific Journal of Sustainable Agriculture Food and Energy 1 (1) : 10-13.

[19] Sugiyono. 2004. Kimia Pangan. Universitas Negeri Yogyakarta. Yogyakarta. $90 \mathrm{p}$.

[20] Manley, D.J.R. 2000. Biscuit, Cracker, and Cookies. Third Edition. New York : CRC Press. 499 p

[21] Lin J.H., H. Singh, Y. T. Chang, dan Y. H. Chang. 2011. Factor Analysis of The Fuctional Properties of Rice Flour From Mutant Genotypes. Journal Food Chemistry 126 : 1108-1114.

[22] Harsoelistyorini, W., S.S. Dewi dan A.C. Kumoro. 2015. Sifat Fisikokimia dan Organoleptik Tepung Mocaf (Modified Cassava Flour) dengan Fermentasi Menggunakan Ekstrak Kubis, Prosiding URECOL.

[23] Fellows PJ. 2000. Food Processing Technology: Principles and Practice. England : Woodhead Publishing.

[24] [BPOM] Badan Pengawas Obat dan Makanan Republik Indonesia. 2008. Pengujian Mikrobiologi Pangan. Hal 7 8.

[25] Fardiaz, S. 1992. Mikrobiologi Pangan I. PT. Gramedia Pustaka Utama. Jakarta. $320 \mathrm{p}$

[26] Sopandi, T. dan Wardah. 2013. Mikrobiologi Pangan Teori dan Praktik. Andi. Yogyakarta. Hal 24-26.

[27] Soekarto, T.S. 1985. Penilaian Organoleptik untuk Industri Pangan dan Hasil Pertanian. Bharata Karya Aksara. Jakarta.

[28] Kemp, S.E. Hollowood T. and Hort J. 2009. Sensory Evaluation of Food Principles and Practices Second Edition. New York : Springer.

[29] Delima, D. 2013. Pengaruh Substitusi Tepung Biji Ketapang (Terminalia catappa) Terhadap Kualitas Cookies. Jurnal Food Science and Culinary Education 2 (2) : 9-15

[30] Meilgaard, M. Civille G.V. and Carr B.T. 2006. Sensory Evaluation and Techniques Fourth Edition. USA : CRC Press.

[31] Marisa, D. 2010. Skripsi : Formulasi Cookies Jagung dan Pendugaan Umur Simpan Produk dengan Pendekatan Kadar Air Kritis. Bogor : Institut Pertanian Bogor 